The Healer's Calling 



\section{The Healer's Calling}

Women and Medicine in Early New England

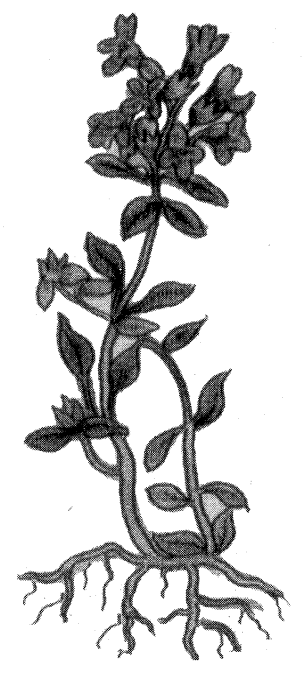

Rebecca J. Tannenbaum 
Copyright ( 2002 by Rebecca J. Tannenbaum

All rights reserved. Except for brief quotations in a review, this book, or parts thereof, must not be reproduced in any form without permission in writing from the publisher. For information, address Cornell University Press, Sage House, 512 East State Street, Ithaca, New York 14850.

First published 2002 by Cornell University Press

First printing, Cornell Paperbacks, 2009

Printed in the United States of America

Library of Congress Cataloging-in-Publication Data

Tannenbaum, Rebecca J. (Rebecca Jo)

The healer's calling : women and medicine in early New England/

Rebecca J. Tannenbaum.

p. $\mathrm{cm}$.

Includes bibliographical references and index.

ISBN 978-0-8014-7493-4

1. Women in medicine-New England-History-17th century. 2. Women in medicine-New England-History-18th century. 3. New England-History-Colonial period, ca. 1600-1775. I. Title.

R692.T364 2002

2001007137

Cornell University Press strives to use environmentally responsible suppliers and materials to the fullest extent possible in the publishing of its books. Such materials include vegetable-based, low-VOC inks and acid-free papers that are recycled, totally chlorine-free, or partly composed of nonwood fibers. For further information, visit our website at www.cornellpress.cornell.edu.

Cloth printing $\quad 10987654321$ 
In memory of my grandmother

Jane Swope Angle and her grandmother

Sadie Traxler Swope

Strength and honor are her clothing; and she shall rejoice in time to come.

PROVERBS 31:25 
